SJ Quinney College of Law, University of Utah Utah Law Digital Commons

$9-2018$

\title{
Point/Counterpoint on the Miranda Decision: Should It Be Replaced or Retained?
}

Paul Cassell

S.J. Quinney College of Law, University of Utah, paul.cassell@law.utah.edu

Amos N. Guiora

S.J. Quinney College of Law, University of Utah

Follow this and additional works at: https://dc.law.utah.edu/scholarship

Part of the Criminal Law Commons

Recommended Citation

Cassell, Paul G., Guiora, Amos N., Utah Bar Journal Vol. 31 No. 5 (2018)

This Article is brought to you for free and open access by the Utah Law Scholarship at Utah Law Digital Commons. It has been accepted for inclusion in Utah Law Faculty Scholarship by an authorized administrator of Utah Law Digital Commons. For more information, please contact valeri.craigle@law.utah.edu. 


\title{
And Prosecutors Now Have an Argument They Can Make to that Effect
}

\author{
by Paul Cassell
}

A

little over fifty years ago, the Supreme Court handed down what may be its most controversial criminal law decision ever - Miranda $v$. Arizona. The decades since then have revealed Miranda to be not only bad constitutional law but also bad public policy. With the benefit of recent experience and modern technology, it is possible to design rules that not only more effectively protect legitimate interests of suspects but also insure that police are not unduly handcuffed as they investigate crimes.

Contrary to the prevailing myth that is often peddled, Miranda's rules have significantly impeded law enforcement's ability to prosecute dangerous criminals. University of Utah Economics Professor Richard Fowles and I have recently assembled all the relevant data on the subject. See Paul G. Cassell \& Richard Fowles, Still Handcuffing the Cops? A Review of Fifty Years of Empirical Evidence of Miranda's Harmful Effects on Law Enforcement, 97 BosT. U.L. Rev. 685 (2017). One source of information comes from the "before-and-after" studies of confession rates in the year or two after the decision. For example, a study in Pittsburgh revealed that confession rates fell from 48\% before the decision to $29 \%$ after. Similar results were reported in Manhattan, Philadelphia, Kansas City, Brooklyn, New Orleans, and Chicago. The few studies to the contrary were done almost immediately after Miranda in jurisdictions where police did not in fact follow all of the decision's procedural rules.

It might be argued that this data about Miranda's harmful effects comes in the immediate wake of the decision and that, since then, police have learned to "live with" Miranda. But surprisingly little hard data has been collected on Miranda's effects. One of the rare exceptions is a study that Bret Hayman and I conducted in the mid-1990s of confession rates in Salt Lake County. Relying on data collected at the Salt Lake District Attorney's Office, we concluded that police collected incriminating statements from suspects in only about $33.3 \%$ of criminal cases in Salt Lake County - a rate well below confession rates generally reported in the country before Miranda. Paul G. Cassell \& Bret S. Hayman, Police Interrogation in the 1990s: An Empirical
Study of the Effects of Miranda, 43 UCLA L. REv. 839, 871 (1996).

Some have argued that this individual study might be an outlier because it would be impossible to say whether Salt Lake County's experience was typical of the nation's. Unfortunately, data on confession rates is not routinely collected in this country to confirm or dispel this argument. But a surrogate measure for confession rates can be found in clearance rates - the rate at which police officers solve or "clear" crimes. The FBI collects clearance rate data from around the country. And defenders of Miranda have argued that clearance rate data shows that police were quickly able to develop new techniques that allowed them to investigate crimes as successfully after the decision as before.

Unfortunately, the FBI's clearance rate data depict a different pattern. As shown in the accompanying graph, crime clearance rates fell immediately after Miranda and have remained substantially below pre-Miranda levels ever since.

Professor Fowles and I have extensively analyzed what factors might have been responsible for this decline in clearance rates. In our article, we report the results of multiple regression equations on crime clearance rates from 1950 to 2012, controlling for factors apart from Miranda that might be responsible for changes in clearance rates. Even controlling for potentially competing factors, we find statistically significant reductions in crime clearance rates after Miranda for violent and property crimes, as well as for robbery, larceny, and vehicle theft - crimes that most likely involved "professional" criminals who were most likely to have

\section{PAUL CASSELL is the Ronald N. Boyce Presidential Professor of Criminal Law at the S.J. Quinney College of Law at the University of Utah. He previously served as a United States District Judge for the District of Utah.}

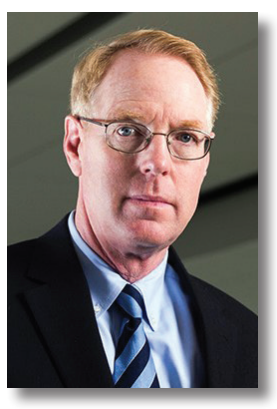




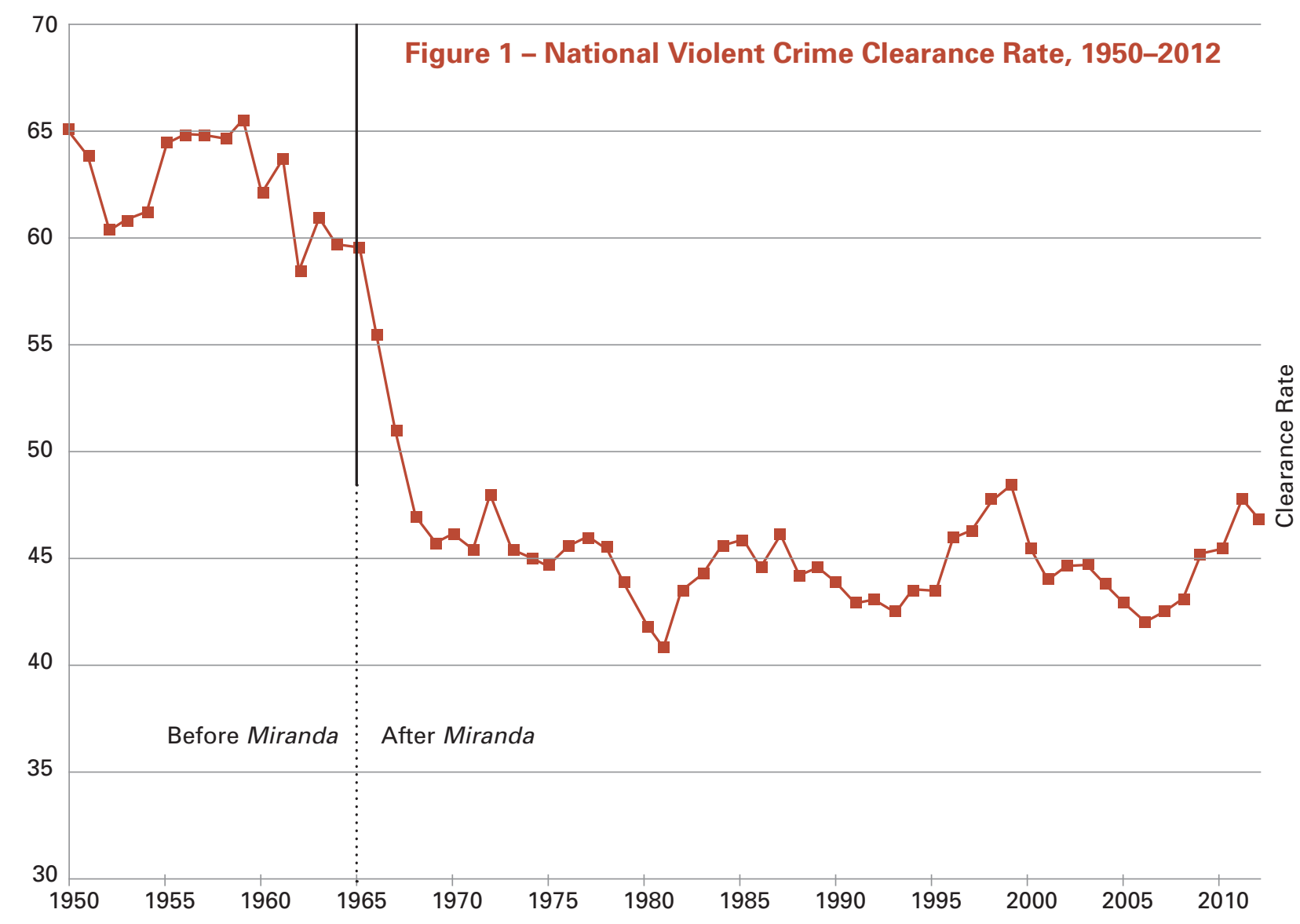

learned how to take advantage of the Miranda rules. We also quantify the number of lost clearances that appear to be due to Miranda, concluding that about 200,000 violent crimes and about 900,000 property crimes might be cleared each year without the Miranda requirements. Cassell \& Fowles, supra, at 732.

My friend and colleague at the S.J. Quinney College of Law, Professor Amos N. Guiora, has recently written a very interesting book discussing the legacy of the Miranda decision. In Earl Warren, Ermesto Miranda, and Terrorism (Twelve Tables Press 2018), Guiora argues that Chief Justice Warren would pay scant attention to such empirical evidence of the calamitous effects that his narrowly divided (5-4) decision had on the nation. In this historical assessment, Guiora is likely correct. When he authored the decision, Chief Justice Warren blithely minimized the warnings of his dissenting colleagues. For example, Justice Harlan warned, "I believe the decision of the Court... entails harmful consequences for the country at large. How serious these consequences may prove to be only time can tell....The social costs of crime are too great to call the new rules anything but a hazardous experimentation." Miranda, 384 U.S. at 504, 517 (1966) (Harlan, J., dissenting).

In reviewing Miranda's legacy, Professor Guiora gamely attempts to credit Miranda with reducing police brutality. But the available data do not support any such linkage. For example, Professor Gerald Rosenberg has comprehensively reviewed the issue, concluding that "[e]vidence is hard to come by but what evidence there is suggests that any reductions that have been achieved in police brutality are independent of the Court and started before Miranda." Gerald N. Rosenberg, The Hollow Hope: Can Courts Bring About Social Change? 326 (1991).

Professor Guiora also refers to Miranda as a "necessary evil." But the Miranda rules are not the only way to approach issues concerning police questioning. Indeed, in the Miranda opinion itself, Chief Justice Warren (at the suggestion of Justice Brennan) stated that the decision "in no way creates a constitutional straitjacket which will handicap sound efforts at reform" and that the Court "encourage[d] Congress and the States to continue their laudable search for increasingly effective ways of protecting the rights of the individual while promoting efficient enforcement of our criminal laws." Id. at 467. Just as in other endeavors of modern life, we have learned a great deal over the last fifty years that could be used to effectively reform the Miranda rules.

One thing that we have learned is that Miranda, if anything, exacerbates the problem of false confessions. Miranda offers essentially no protection to vulnerable innocent persons who erroneously fall under police suspicion, such as intellectually disabled suspects. Such persons typically eagerly waive their Miranda rights and may ultimately, in some rare cases, be induced to offer false confessions. On the other hand, as the 
clearance rate data above suggest, professional criminals are the most likely to invoke Miranda questioning cut-off rules, blocking any questioning whatsoever. As many academics who have closely studied Miranda have concluded, the upshot is that Miranda's rules "shielded some savvy, guilty recidivists while doing little to protect the [intellectually disabled], juveniles, and other innocent defendants most likely to confess." Stephanos Bibas, The Right to Remain Silent, 158 U. PA. L. Rev. Penumbra 69, 77 (2010). Indeed, it seems likely that by diverting judicial attention towards procedural issues of Miranda compliance and away from underlying "voluntariness" questions, Miranda has affirmatively harmed vulnerable persons who have given false confessions.

One solution to such problems is to videotape police interrogations, as many commentators have recognized. Electronic recording of interrogations allows later judicial review to more powerfully detect false confessions and inappropriate police techniques that are sometimes hard to review without an objective record. Interestingly, many police agencies (including Utah agencies) currently electronically record interrogations, subject to certain limited exceptions. Videorecording provides far more protection against coercive tactics and "false" confessions than the Miranda rules ever did.

In a case where police interrogation has been recorded, prosecutors in Utah and elsewhere should consider advancing parallel arguments to trial courts. In addition to the standard arguments about Miranda compliance or inapplicability, prosecutors should also argue that the Miranda regime is no longer necessary to satisfy the requirements of the Fifth Amendment. As noted above, Miranda itself encouraged the states to explore other ways to protect suspects' rights. Electronic recording is such a means. And, since 1966, a whole host of changes have occurred in American policing, such as greater training and professionalization, that means that any arguable need for such rules is much weaker today.

Excluding reliable evidence should always be a last resort. As Justice Lee recently explained in connection with the search and seizure exclusionary rule, "[I] ts bottom-line effect, in many cases, is to suppress the truth and set the criminal loose in the community without punishment." State v. Rowan, 2017 UT 88, ๆ 52, 416 P.3d 566 (Lee, J., concurring). Where a defendant seeks to exclude his or her voluntary confession under Miranda, suppressing the confession can similarly lead to a miscarriage of justice. Contrary to Professor Guiora's suggestion, a court rule like Miranda that automatically and often arbitrarily excludes a confession, without regard to its reliability or voluntariness, by definition favors criminals over victims.

With its historical focus, Professor Guiora's article harkens back to the turmoil of the 1960s, when Chief Justice Warren engaged in what has to be regarded as the paradigm example of judicial legislation. But in the decades since Warren penned Miranda, the Supreme Court has repeatedly held that the Miranda rules are not themselves constitutional rights but are mere "prophylactic safeguards" - presumably subject to appropriate modification by Congress or the states. To be sure, in one post-Miranda case, the Supreme Court rejected an argument that a sufficient alternative had been put in place of the Miranda rules. That was Dickerson $v$. United States, 530 U.S. 428 (2000), a case I argued to the Supreme Court. But in that case, the alternative to Miranda was, according to the Dickerson majority, nothing other than a federal statute authorizing a return to the pre-Miranda voluntariness rules. Videotaping, of course, is not something that was mandated (or even readily available) before Miranda. Thus, a prosecutor could make a very strong alternative argument that videotaping (along with other safeguards) serves as a legitimate substitute for the prophylactic Miranda requirements under the U.S. Constitution. And in Utah (as in many other states), the state constitution has never been interpreted as imposing the novel Miranda requirements as a matter of state constitutional law. See State v. Leyva, 951 P.2d 738, 743 (Utah 1997) ("“[T] his Court has never specifically held that Miranda-type warnings are required under the Utah Constitution"”.) (citation omitted).

Videotaping deters genuine police misconduct more effectively than Miranda by creating a clear record of police and suspect demeanor during questioning. To be sure, police can turn off videocameras or deploy force off-camera. But if you were facing a police officer with a rubber hose, would you prefer a world in which he was required to mumble the Miranda warnings and have you give some form of waiver of rights (all proven by his later testimony)? Or a world in which the interrogation is videorecorded, where your physical appearance and demeanor during any "confession" are permanently recorded, where date and time are electronically stamped on the tape? Videotaping is the clear winner.

In closing, I agree with Professor Guiora that protecting constitutional rights is as important in 2018 as it was in 1966. But it is folly to think that the unprecedented rules Chief Justice Warren thought would best serve the country at the time should remain frozen in time as the only way to address constitutional issues involved in police questioning. More than fifty years later, prosecutors in Utah and elsewhere can now argue that, with more modern tools like videotaping often available and more professional police training for law enforcement officers, a different world exists. This legal regime still requires that police refrain from coercive tactics that obtain involuntary statements. But when police have obtained a clearly voluntary statement from a suspect as documented by videorecorded evidence, the technical Miranda rules should be regarded as superseded relics of an outmoded and harmful prophylactic regime. 


\author{
by Amos N. Guiora
}

Interrogations reflect an imbalance between the interrogator and suspect, a nitty-gritty confluence of fear, anxiety, and control.

My "counter-point" to Professor Cassell's thoughtful and well argued "point" reflecting path-breaking empirical research that has drawn, justifiably, wide commentary, focuses on interrogations from the suspect's perspective. That is in accordance with the essence of the holding in Miranda v. Arizona.

Chief Justice Earl Warren emphasized the vulnerability of the individual in the inherently coercive environment of an interrogation. For Warren, as for me, the power, importance, and centrality of Miranda is the focus on protecting the constitutional rights of the vulnerable individual. That is the theme of this counterpoint; I believe this approach most accurately represents what $J$ Warren believed and wrote in as clear a language as possible. Warren's holding guaranteed the protection of a right guaranteed in the Constitution to an individual.

Any proposed weakening of Miranda, beyond the Quarles exception, would represent unwarranted evisceration; while body cams or any other technological tools are doubtlessly valuable, they must not come in the place of the interrogator's clear articulation to the suspect of his/her Miranda rights.

I am of the opinion that these words are amongst the most important ever penned in a Supreme Court decision. As simple as they are, they are majestic.

You have the right to remain silent. Anything you say can and will be used against you in a court of law. You have the right to an attorney. If you cannot afford an attorney, one will be provided for you. Do you understand the rights I have just read to you? With these rights in mind, do you wish to speak to me?

\section{Introduction:}

To solve a crime, the interrogator needs information. The essence of police work is gathering information, collecting evidence, connecting various dots, and then determining who is responsible for violating the law. There is nothing magical about this. While contemporary methods are more sophisticated, more scientifically based and, hopefully, more objective than in years past, the critical interaction is between the two individuals.

As Earl Warren fully understood, that relationship is at the epicenter of criminal law and procedure. The interrogator wants the truth. That is the purest form of law enforcement in the ideal. What Warren feared was an interrogator who wants a confession and for the suspect to incriminate himself or herself and say, "I did it" regardless of the truth. That is an interrogator who coerces a confession from the suspect.

If there is one word that captures the interrogation paradigm it is "coercive." While the environment is not intended to resemble comfort and leisure, the question is to what degree does the suspect have to be coerced before confessing. The environment - in its totality - is coercive. Coercion is inherent to interrogation. The physicality is obvious and telling. The suspect is handcuffed. The suspect is accused of having committed a crime.

\section{Miranda v. Arizona}

Chief Justice Earl Warren sought to protect the vulnerable; he clearly understood the realities of the interrogation paradigm. Warren, based on his experiences as a District Attorney, was fully cognizant of the inherent imbalance between the interrogator and the suspect. As the opinion made clear, Warren recognized interrogations are inherently coercive.

His motivations were simultaneously simple and profound; simple in that he wanted to protect suspects, profound in that he imposed

AMOS GUIROA is a Professor of Law at the S.J. Quinney College of Law at the University of Utah. He is the author of The Crime of Complicity: The Bystander in the Holocaust $(A B A, 2017)$ and Earl Warren: Ernesto Miranda and Terrorism (Twelve Tables Press, 2018).

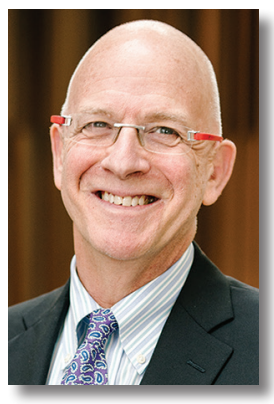


limits on how the nation state interacted with vulnerable individuals. That is, in protecting those suspected of criminal activity, Warren sent a clear message to law enforcement and society. That message, while focusing on the specific individual, also had powerful consequences regarding the larger society.

The opinion was not written in a vacuum; America in 1966 was in turmoil. The Harlem and Watts riots of 1964 and 1965 dramatically and violently highlighted profound anger, resentment, and social injustice. The Detroit and Newark riots in 1967 and the riots that followed the assassination of Dr. King in 1968 were extremely violent, resulting in significant loss of life, requiring intervention by the U.S. military. In between those two "book-ends," Earl Warren's Supreme Court imposed limits on law enforcement.

While law enforcement loudly complained that the decision "handcuffed" police officers, Earl Warren believed protecting the individual was paramount. The tension between these two perspectives must be acknowledged. It would not be an exaggeration to use the phrase "necessary evil" in describing how Miranda is perceived in certain quarters.

There is no indication Detective Carroll Cooley pressured or coerced Ernesto Miranda during the course of the interrogation. Arguably, that was a strategic decision by Warren: there was nothing unusual or extraordinary in how Miranda was interrogated; it was a run-of-the-mill interrogation conducted in the aftermath of a crime with nothing to indicate its uniqueness. Miranda was not subject to a violent, physical interrogation conjured up in images of sheriff deputies beating African-American suspects in the back seat.

Viewing the case in that context increases the power of the holding; were Miranda the victim of a back-seat beating then it would be possible to dismiss the opinion suggesting, "of course the suspect has to be protected; otherwise, he'll come within a whisker of a brutal death." That dismissiveness cannot be applied given how Cooley interrogated Miranda. The facts of Miranda's interrogation lent themselves to Warren's decision to "use" Miranda as the platform to extend Escobedo.

It is not by chance that Warren penned the opinion himself. Unlike his fellow justices, Warren had been elected to serve as district attorney and had intimate knowledge of the interrogation paradigm. ${ }^{1}$ The opinion is neither complex nor sophisticated; it is written in a manner that any member of the public and law enforcement can easily understand. There is no hidden ball and no "between the lines" analysis required to comprehend its full import. This was a clear directive; this was not the time or place for nuance. The message was unequivocal.

For Warren, the most effective way to protect the suspect was to inform the suspects that they had the right to remain silent and that, if need be, an attorney would be provided. The obligation imposed on the interrogator was two-fold: to read the suspect the warning and to ensure that the suspect understood the rights granted. Whether the suspect chose to exercise the right or to "waive" was a personal decision. To be made by the suspect.

The decision represents recognition of the mistreatment of suspects throughout history. That is an extraordinarily important acknowledgment both for the specific suspect and for the relationship between the state and the individual. The decision is powerful on a micro and macro scale alike.

\section{Protecting the suspect was essential.}

There is no doubt Warren was fully aware of the injustices that had been visited upon suspects over the years. In establishing a rights-based interrogation regime, Warren was also protecting larger society from the consequences of confessions elicited from mistreated suspects. Warren was concerned about the lack of professionalism amongst police departments; he believed coerced confessions reflected laziness amongst police officers. In addition, coerced confessions resulted in wrongful convictions. The consequences from all perspectives were, for Warren, deeply troubling.

In establishing the Miranda warnings, Warren and the four justices who joined him took a clear and bold stand regarding interrogations. Admittedly long, the opinion explains the core issue in a manner that left no doubt as to the writer's intention. The language is neither soaring nor particularly elegant. The prose is not of a poet; Warren was neither bard nor man of letters. The directness conveys a powerful message to interrogators: ENOUGH.

Emphasizing the suspect's Fifth Amendment privilege against self-incrimination was the cornerstone of the decision; the "right to remain silent" is the practical, jurisprudential, and existential core of the opinion. For Warren, protecting that constitutionally guaranteed privilege was of the essence. It is not an exaggeration to suggest that, for Warren, it was sacrosanct. The opinion must be read accordingly.

The centerpiece of the decision was ensuring the suspect be protected from state agents.

That does not mean, as some have suggested, that Warren minimized harm caused to the victim of a crime. I believe that to be a spurious charge. One must not forget that Warren well understood victims' pain; his own father had been murdered. Warren was sympathetic to the victim; however, he differentiated between the victim's unquestioned harm and suffering and the individual suspected of having committed the crime in question. 
The difference is significant: the victim was clearly identified, the suspect but a suspect. Protecting the rights of the latter does not, in any way, trivialize or disrespect the suffering of the former. To suggest that Warren preferred one over the other or was more sympathetic to suspects than to victims is erroneous. It also significantly misses the point of the opinion and what was of grave concern to the majority. The opinion was neither victim "unfriendly" nor suspect "friendly." That is to miss the point. Rather, Earl Warren, as Chief Justice of the U.S. Supreme Court, sought to ensure that basic constitutional rights were protected in the interrogation setting and that law enforcement respected the rights of the suspect.

Below are excerpts from the opinion which Warren read in its entirety on June 13, 1966.

The cases before us raise questions which go to the roots of our concepts of American criminal jurisprudence: the restraints society must observe consistent with the Federal Constitution in prosecuting individuals for crime. More specifically, we deal with the admissibility of statements obtained from an individual who is subjected to custodial police interrogation and the necessity for procedures which assure that the individual is accorded his privilege under the Fifth Amendment to the Constitution not to be compelled to incriminate himself.

By custodial interrogation, we mean questioning initiated by law enforcement officers after a person has been taken into custody or otherwise deprived of his freedom of action in any significant way.

Prior to any questioning, the person must be warned that he has a right to remain silent, that any statement he does make may be used as evidence against him, and that he has a right to the presence of an attorney, either retained or appointed. The defendant may waive effectuation of these rights, provided the waiver is made voluntarily, knowingly and intelligently. If, however, he indicates in any manner and at any stage of the process that he wishes to consult with an attorney before speaking, there can be no questioning. Likewise, if the individual is alone and indicates in any manner that he does not wish to be interrogated, the police may not question him. The mere fact that he may have answered some questions or volunteered some statements on his own does not deprive him of the right to refrain from answering any further inquiries until he has consulted with an attorney and thereafter consents to be questioned.
The constitutional issue we decide in each of these cases is the admissibility of statements obtained from a defendant questioned while in custody or otherwise deprived of his freedom of action in any significant way.

\section{Who is in Control: What Needs Protection?}

Control is critical to understanding interrogation. Who controls, who is controlled. The struggle is intense, intensive, high-stakes, and constant. That is fair enough and not surprising. The question is whether the "game" is played within acceptable rules and boundaries.

As Warren wrote, interrogations were inherently coercive, and suspects had to be protected. Warren did not say "all" detectives violated suspect rights for that would be an unjustified exaggeration, casting unwarranted aspersions on the law enforcement community; he did, however, make it crystal clear that how interrogations were conducted had to change. And the change that was required had one intention: to protect the suspect whose rights, according to Warren, must be protected.

Did Warren anger detectives? Safe to assume. Were "clean" detectives made to feel "guilty"? Probably. Was the public angry? Certainly, a segment. No doubt about that.

In describing interrogations as coercive, Warren threw the gauntlet down.

For all the seeming fairness, protection, and process that appear to be in place, the reality is the following: The suspect exercises little, if any control, in the interrogation setting. That's just the way it is. ${ }^{2}$

That lack of control, the dependence on the interrogator, the inability to withstand pressure - whether real or imagined - is what defines the interrogation setting.

Protecting constitutional rights is as important in 2018 as in 1966.

Protecting a suspect's rights is as important in 2018 as it was in 1966.

Based on my research, I am convinced CJ Warren would wholeheartedly concur with both conclusions.

1. Justice Tom Clark served as an assistant district attorney, https://www.oyez.org/ justices/tom_c_clark.

2. For more on interrogations, see: Wrongful Convictions, Rights Violated During Police Interrogation, YouTube (Nov. 16, 2014), https://www.youtube.com/ watch?v=rM1bVvPTL6g; https://www.youtube.com/watch?v=Z-VW8Ldw6YI 